\title{
Phytochemical and Antibacterial Studies of the Hexane Extract of Alchornea cordifolia Leaf
}

\author{
G.O. Adeshina ${ }^{1, *}$, O.F. Kunle ${ }^{2}$, J.A. Onaolapo ${ }^{1}$, \\ J.O. Ehinmidu ${ }^{1}$ and L.E. Odama ${ }^{3}$ \\ ${ }^{1}$ Department of Pharmaceutics and Pharmaceutical Microbiology, \\ Ahmadu Bello University, Zaria, \\ ${ }^{2}$ Department of Medicinal Plant Research, \\ National Institute for Pharmaceutical Research and Development, Idu - Abuja, \\ ${ }^{3}$ Department of Biological Sciences, Kogi State University, Anyingba, \\ Nigeria
}

\section{Introduction}

Alchornea cordifolia (Schum. \& Thonn.) Muel. Arg. (Euphorbiaceae) is also known as Agyama in Ghana, Susu bolonta in Sierra Leone, Casamance bugong in Senegal, Tschiya in Togo, Bondji in Cameroon, Ewe ipa, Ubobo and Bambami in Nigeria. It is geographically distributed in secondary forest usually near water, moist or marshy places and it grows to a considerable height but is always of a shrubby or scrambling habit.

The plant leaf extracts have been reportedly used in various African countries such as Senegal in the treatment of venereal diseases, conjunctivitis, dermatoses, stomach ulcers, bronchitis, cough, toothache (Le Grand and Wondergem, 1987; Le Grand, 1989). In Zaire it was used in the treatment of urinary tract infections, infected wounds, diarrhoea, cough, dental caries, chest pain and anaemia (Kambu et al., 1990; Muanza et al., 1994). In Sierra Leone it was used for diarrhoea and piles (Dalziel, 1956; Macfoy and Sama, 1990) and in Nigeria for gonorrhoea, yaws, rheumatic pain and cough (Gbile and Adeshina, 1986; Ogungbamila and Samuelson, 1990).

A variety of plants or materials derived from plants are been used for the prevention and treatment of diseases virtually in all cultures. The potential of herbal medicines and medicinal plant research results in health care is no longer in doubt, having gained recognition in several nations of the world and the World Health Organisation (WHO).

Secondary metabolites which constitute important source of the pharmaceutical preparations have been reportedly isolated from different parts of plants. Some of these compounds have been reported to be present in A. cordifolia such as flavonoids (Ogungbamila and Samuelson, 1990), alkaloids and tannins (GHP, 1992), inulin and alchornine (Abdullahi et al., 2003). 
This work tends to investigate the phytochemical components and antibacterial activities of hexane extract.

\section{Materials and methods}

\subsection{Collection, identification and preparation of plant leaf}

Alchornea cordifolia leaves were collected in October from Abuja, Nigeria. They were authenticated in the herbarium of the National Institute for Pharmaceutical Research and Development (NIPRD), Abuja, Nigeria where a voucher with specimen number 4334 was kept for future reference. The leaves were air-dried at room temperature and then reduced to powder using mortar and pestle.

\subsection{Preparation of the extract and its derived fractions}

Using the Soxhlet extractor, 300 gm of the powdered leaves was extracted with $450 \mathrm{ml}$ of hexane at room temperature until all the extractable components were exhausted. The extract was concentrated, dried, weighed and kept in a dessicator until needed.

Hexane extract was analysed for chemical composition using the bioassay-guided fractionation by employing the Accelerated Gradient Chromatography (AGC) technique. Silical gel G (E-Merck, Germany) was used as an absorbent. Gradient elution was effected using hexane and ethyl acetate sequentially with increasing polarity. A total of 77 fractions were collected. The thin layer chromatography (TLC) analyses of the fractions were carried out using Whatman TLC plates of size $10 \times 20 \mathrm{~cm}$ precoated with K5 silical gel 150A (Whatman Limited Maidstone, England). The chromatograms were developed using solvent mixture specific for separating alkaloid compounds especially hexane and ethyl acetate, 3:1. After development, the chromatograms were dried and detection was made using ultraviolet light at both wavelength $254 \mathrm{~nm}$ and $365 \mathrm{~nm}$. Similar fractions were pooled together giving 33 fractions.

\subsection{Phytochemical screening of the hexane extract}

The extract was subjected to phytochemical analysis to detect the presence of the chemical constituents using standard protocol (Trease and Evans 1996).

\subsection{Extraction of the secondary metabolites}

Extraction of the secondary metabolites present in the hexane extract was also carried out using standard methods of Marcek (1972).

\section{Antimicrobial activity}

\subsection{Purification of organisms}

The organisms: Pseudomonas aeruginosa ATCC 10145, Staphylococcus aureus ATCC 12600 and Escherichia coli ATCC 11775 were collected from the Department of Pharmaceutical Microbiology, University of Benin, Benin City, Nigeria. While the clinical isolalates Pseudomonas aeruginosa, Staphylococcus aureus, Escherichia coli and Proteus sp. were from the 
Staff Clinic, National Institute for Pharmaceutical Research and Development, Abuja, Nigeria. The organisms were confirmed by sub-culturing into Nutrient broth and incubated at $37{ }^{\circ} \mathrm{C}$ for 18 hours.

They were further streaked on the Nutrient agar and incubated at $37^{\circ} \mathrm{C}$ for 18 hours. Biochemical tests were used to confirm the organisms. The organisms were kept on agar slants at $4^{\circ} \mathrm{C}$ until needed.

\subsection{Preparation of inoculums}

Eighteen-hour broth culture of the test organism was suspended into sterile nutrient broth. It was standardized according to National Committee for Clinical Laboratory Standards (NCCLS, 2002) by gradually adding normal saline to compare its turbidity to McFarland standard of 0.5 which is approximately $1.0 \times 10^{6} \mathrm{cfu} / \mathrm{ml}$.

\subsection{Susceptibility testing}

The washed overnight broth cultures were diluted appropriately using sterile normal saline to $0.5 \mathrm{McF}$ arland scales $\left(0.5 \mathrm{McF}\right.$ arland is about $\left.10^{6} \mathrm{cfu} / \mathrm{ml}\right)$. The molten sterile nutrient agar $(20 \mathrm{ml})$ was poured into sterile petri dish and allowed to set. The sterile nutrient agar plate was flooded with $1.0 \mathrm{ml}$ of the standardized test organism and the excess was drained off and dried at $30^{\circ} \mathrm{C}$ for $1 \mathrm{hr}$. A sterile cork borer (No. 4) was used to bore equidistant cups into the agar plate. One drop of the molten agar was used to seal the bottom of the bored hole, so that the extract will not sip beneath the agar. $0.1 \mathrm{ml}$ of the different concentrations $(0.625-20.0 \mathrm{mg} / \mathrm{ml})$ of the extract was added to fill the bored holes. Negative control was prepared by putting $0.1 \mathrm{ml}$ of pure solvent in one of bored hole and aqueous solution of $2 \mu \mathrm{g}$ of Gentamicin (for Gram positive bacteria) and $4 \mu \mathrm{g}$ of Gentamicin (for Gram negative bacteria) (Sweetman, 2005) in another bored hole which served as positive control. One hour pre-diffusion time was allowed, after which the plates were incubated at $37^{\circ} \mathrm{C}$ for $18 \mathrm{~h}$. The zones of inhibition were then measured in millimeter. The above method was carried out in triplicates and the mean of the triplicate results was taken.

\subsection{Minimum Inhibitory Concentration (M.I.C.) and Minimum Bactericidal Concentration (M. B. C.)}

The M.I.C. was determined by agar dilution method. Ten millilitre $(10 \mathrm{ml})$ volume of double strength melted Mueller-Hinton agar at $45^{\circ} \mathrm{C}$ was diluted with equal volume of the test extract in graded concentrations of $0.625-20.0 \mathrm{mg} / \mathrm{ml}$. These were poured aseptically into sterile Petri dishes and dried at $37^{\circ} \mathrm{C}$ for $1 \mathrm{~h}$ with the lid slightly raised. The solidified leaf extract-agar admixture plates were inoculated with $2.0 \mu \mathrm{l}$ of standardized $18 \mathrm{~h}$ culture test organism. The inocula were allowed to diffuse into the test agar plates for $30 \mathrm{~min}$. The test agar plates were then incubated at $37^{\circ} \mathrm{C}$ for $18 \mathrm{~h}$. The M.I.C. value was taken as the least concentration of the extract showing no detectable growth.

The M. B. C. was carried out by inoculating the concentration of the extract in the test agar plates showing no visible growth into sterile nutrient broth test-tubes containing inactivating agents $3 \% \mathrm{v} / \mathrm{v}$ Tween 80 . These test-tubes were then incubated at $37^{\circ} \mathrm{C}$ for $24 \mathrm{~h}$ after which they were examined for presence or absence of growth. 


\subsection{Preliminary antimicrobial activity test of the various fractions from the hexane extract}

Exactly $5.0 \mathrm{ml}$ of $20.0 \mathrm{mg} / \mathrm{ml}$ of the fraction was incorporated into $5.0 \mathrm{ml}$ molten double strength sterile nutrient agar kept at $45^{\circ} \mathrm{C}$ and poured into sterile Petri dishes and allowed to set. The test organism was streaked on the poured plate and incubated at $37^{\circ} \mathrm{C}$ for 24 hours after which the activity/no activity was observed.

\section{Results}

The hexane extract (HE) of Alchornea cordifolia leaves was brown in colour. There was a yield of $40.22 \%$ of the extract.

The phytochemical screening of the hexane extract of $A$. cordifolia leaf revealed the presence of tannins, alkaloids, flavonoids and phenol with tannins having the highest percentage yield of 6.8 (Table 1).

\begin{tabular}{|l|c|}
\hline Secondary Metabolites & Yield (\%) \\
\hline Tannins & 6.8 \\
\hline Alkaloids & 5.9 \\
\hline Flavonoids & 4.2 \\
\hline Phenol & 3.2 \\
\hline
\end{tabular}

Table 1. Percentage yield of the secondary metabolites from the hexane extract of $A$. cordifolia leaf.

The susceptibility of the bacteria species to the secondary metabolites of the plant showed that test Staphylococcus aureus was more susceptible to the secondary metabolites than the other bacteria species (Table 2). The zones of inhibition observed from tannins and saponin were larger than those from the other metabolites (Table 2).

\begin{tabular}{|l|c|c|c|c|}
\hline \multirow{2}{*}{ Test bacteria species } & \multicolumn{4}{|c|}{ Zones of inhibition (mm) } \\
\cline { 2 - 5 } & Tannin & Saponin & Alkaloids & Phenols \\
\hline Ps.aeruginosa & $24 \pm 0.1$ & $20 \pm 0.2$ & $16 \pm 0.0$ & $14 \pm 0.0$ \\
\hline Ps.aeruginosa ATCC 10145 & $21 \pm 0.1$ & $19 \pm 0.1$ & $18 \pm 0.1$ & $15 \pm 0.1$ \\
\hline Staph. aureus & $26 \pm 0.3$ & $21 \pm 0.1$ & $20 \pm 0.0$ & $17 \pm 0.2$ \\
\hline Staph. aureus ATCC 12600 & $22 \pm 0.1$ & $18 \pm 0.2$ & $21 \pm 0.1$ & $16 \pm 0.0$ \\
\hline E.coli & $19 \pm 0.2$ & $16 \pm 0.2$ & $16 \pm 0.0$ & $13 \pm 0.1$ \\
\hline E.coli ATCC 11775 & $15 \pm 0.0$ & $14 \pm 0.2$ & $12 \pm 0.1$ & $11 \pm 0.3$ \\
\hline Proteus sp. & $20 \pm 0.0$ & $22 \pm 0.3$ & $17 \pm 0.2$ & $12 \pm 0.1$ \\
\hline
\end{tabular}

Table 2. Susceptibility of the bacterial species to the secondary metabolites of the hexane extract of A. cordifolia leaf.

The clinical isolate of Staphylococcus aureus was more susceptible to the hexane extract of the plant leaf than the other bacterial species (Table 3).

The lowest Minimum Inhibitory Concentration of the hexane extract was found to be $2.5 \mathrm{mg} / \mathrm{ml}$ against Staph. aureus and Staph. aureus ATCC 12600 (Table 4). 


\begin{tabular}{|l|c|c|c|c|c|c|}
\hline \multirow{2}{*}{ Test bacteria } & \multicolumn{5}{|c|}{ Zones of Inhibition (mm) } \\
\cline { 2 - 7 } & $20 \mathrm{mg} / \mathrm{ml}$ & $10 \mathrm{mg} / \mathrm{ml}$ & $5 \mathrm{mg} / \mathrm{ml}$ & $2.5 \mathrm{mg} / \mathrm{ml}$ & $1.25 \mathrm{mg} / \mathrm{ml}$ & GTM \\
\hline Ps.aeruginosa & $13 \pm 0.2$ & $11 \pm 0.1$ & NI & NI & NI & $31 \pm 0.0$ \\
\hline Ps.aeruginosa ATCC 10145 & $11 \pm 0.0$ & NI & NI & NI & NI & $32 \pm 0.2$ \\
\hline Staph. aureus & $23 \pm 0.0$ & $19 \pm 0.1$ & $18 \pm 0.2$ & $14 \pm 0.2$ & NI & $23 \pm 0.0$ \\
\hline Staph. aureus ATCC 12600 & $22 \pm 0.2$ & $17 \pm 0.0$ & $15 \pm 0.1$ & $12 \pm 0.2$ & NI & $25 \pm 0.1$ \\
\hline E.coli & $11 \pm 0.2$ & NI & NI & NI & NI & $20 \pm 0.2$ \\
\hline E.coli ATCC 11775 & $16 \pm 0.1$ & $14 \pm 0.3$ & $11 \pm 0.1$ & NI & NI & $22 \pm 0.0$ \\
\hline Proteus sp. & $15 \pm 0.2$ & $13 \pm 0.0$ & $11 \pm 0.1$ & NI & NI & $21 \pm 0.0$ \\
\hline
\end{tabular}

The results are expressed as mean \pm standard deviation, GTM $=$ Gentamicin, NI = No Inhibition.

Table 3. Susceptibility of the bacterial species to different concentrations of the hexane extract of A. cordifolia leaf.

\begin{tabular}{|l|c|c|}
\hline Test Bacteria & MIC $(\mathrm{mg} / \mathrm{ml})$ & MBC $(\mathrm{mg} / \mathrm{ml})$ \\
\hline Ps. aeruginosa & 20 & NA \\
\hline Ps.aeruginosa ATCC 10145 & NA & NA \\
\hline Staph. aureus & 2.5 & 5 \\
\hline Staph. aureus ATCC 12600 & 2.5 & NA \\
\hline E .coli & 20 & 20 \\
\hline E. coli ATCC 11775 & 10 & 20 \\
\hline Proteus sp. & 10 & \\
\hline
\end{tabular}

Key: NA - No Activity

Table 4. M. I. C. and M. B. C. of the hexane extract against the test bacteria species.

\begin{tabular}{|l|c|c|c|c|c|c|c|}
\hline Fractions & $\begin{array}{l}\text { Ps. } \\
\text { aeruginosa }\end{array}$ & $\begin{array}{l}\text { Ps. aeruginosa } \\
\text { ATCC 10145 }\end{array}$ & $\begin{array}{l}\text { Staph. } \\
\text { aureus }\end{array}$ & $\begin{array}{l}\text { Staph. aureus } \\
\text { ATCC } 12600\end{array}$ & $\begin{array}{l}\text { E. coli } \\
\text { E. coli ATCC } \\
11775\end{array}$ & $\begin{array}{l}\text { Proteus } \\
\text { sp. }\end{array}$ \\
\hline $\mathrm{HEF}_{1-17}$ & - & - & - & - & - & - & - \\
\hline $\mathrm{HEF}_{18}$ & - & - & IN & - & - & IN & IN \\
\hline $\mathrm{HEF}_{19}$ & - & - & IN & - & - & IN & IN \\
\hline $\mathrm{HEF}_{20}$ & - & - & IN & IN & - & IN & IN \\
\hline $\mathrm{HEF}_{21}$ & + & + & + & + & - & - & - \\
\hline $\mathrm{HEF}_{22}$ & - & - & IN & - & - & - & - \\
\hline $\mathrm{HEF}_{23}$ & - & - & IN & - & - & - & - \\
\hline $\mathrm{HEF}_{24}$ & - & - & IN & - & - & - & - \\
\hline $\mathrm{HEF}_{25}$ & - & - & IN & - & - & - & - \\
\hline $\mathrm{HEF}_{26}$ & IN & IN & IN & IN & - & - & - \\
\hline $\mathrm{HEF}_{27}$ & + & + & + & + & IN & IN & IN \\
\hline $\mathrm{HEF}_{28}$ & + & + & + & + & + & + & + \\
\hline $\mathrm{HEF}_{29}$ & IN & IN & IN & IN & IN & IN & IN \\
\hline $\mathrm{HEF}_{30}$ & + & + & + & + & + & + & + \\
\hline $\mathrm{HEF}_{31}$ & + & + & - & - & - & - & - \\
\hline $\mathrm{HEF}_{32}$ & - & - & IN & IN & - & - & - \\
\hline $\mathrm{HEF}_{33}$ & - & - & - & - & + & + & + \\
\hline
\end{tabular}

KEY: - = No Activity, IN = Inhibitory or bacteristatic, + = Activity or bactericidal

Table 5. Antibacterial activity of fractions of hexane extract of Alchornea cordifolia. 
The hexane extract fractions (HEF) $1-17$ showed no antibacterial activity against any of the bacteria species while $\mathrm{HEF}_{29}$ had bacteristatic effect and HEF 28, 30 had bactericidal effect against all the bacteria species (Table 5).

\section{Discussion}

The results from the phytochemical screening of the hexane extract revealed the presence of tannins, saponins, alkaloids and phenol. Several plants which are rich in tannins have been shown to possess antibacterial activities against a number of microorganisms (Doss et al., 2009). Saponnins though are haemolytic on red blood cells, are harmless when taken orally and they have beneficial properties of lowering cholesterol levels in the body (Amos-Tautua et al., 2011). Alkaloids have been shown to possess both antibacterial (Erdemoglu et al., 2009) and antidiabetic (Costantino et al., 2003) activities. Phenols and phenolic compounds have been extensively used in disinfections and remain the standard with which other bactericides are compared (Uwumarongie et al., 2007).

The antibacterial activities exhibited by the secondary metabolites: tannins, saponins, alkaloids, and phenols extracted from the hexane extract of $A$. cordifolia leaf can be responsible for the antibacterial activity of the extract. The presence of secondary metabolites in plants have been reported to be responsible for their antibacterial properties (Rojas et al., 2006; Nikitina et al., 2007; Udobi et al., 2008; Rafael et al., 2009; Adeshina et al., 2010). The broad spectrum of antibacterial activity showed by the hexane extract against Gram positive and Gram negative bacteria can be attributed to the presence of the secondary metabolites. All the secondary metabolites showed more antibacterial activity against the gram-positive bacteria than the gram-negative bacteria. This is similar to the results of Adeshina (2005) who discovered that tannins, saponin, alkaloid and phenol from the leaf methanol, water and ethyl acetate extracts of Alchornea cordifolia had antibacterial activities against gram-positive bacterial strains more than gram-negative bacteria. Banso and Adeyemo (2007) also detected that tannins and alkaloids from Dichrostachys cinerea possessed antibacterial activities against grampositive bacterial strains more than gram-negative bacteria.

The hexane extract appeared to be more active against the gram positive bacteria, Staph. aureus, than the Gram negative bacteria species. Gram negative bacteria are known to be resistant to the action of most antibacterial agents including plant based extracts and these have been reported by many workers (Kambezi and Afolayan, 2008; El-Mahmood, 2009). Gram negative bacteria have an outer phospholipids membrane with the structural lipopolysaccharide components, which make their cell wall impermeable to antimicrobial agents.

The bactericidal action of $\mathrm{HEF}_{28}$ and $\mathrm{HEF}_{30}$ against all the tested bacteria species can be an indication that these fractions possess the active ingredients responsible for antibacterial activity of the hexane extract of Alchornea cordifolia leaf. $\mathrm{HEF}_{21}$ and $\mathrm{HEF}_{27}$ displayed notable antibacterial activities against Staph. aureus and Pseudomonas aeruginosa that is of great importance because the infections cause by these bacteria are known to be difficult to control. Staphylococcus aureus has been reported by many workers to have developed resistance to most antibiotics and Pseudomonas aeruginosa is an opportunistic organism which has been reported to readily receive resistance carrying plasmid from other bacteria species (Wiley et al., 2008). $\mathrm{HEF}_{33}$ also showed noteworthy bactericidal action against the 
tested enteric bacteria-E. coli and Proteus $s p$. Enteric bacteria are known to transmit resistance plasmid among themselves (Brooks et al., 2008) therefore developing resistance to many antibiotics. In view of all these observations, these fractions: $\mathrm{HEF}_{28}, \mathrm{HEF}_{30}, \mathrm{HEF}_{21}$, $\mathrm{HEF}_{27}$ and $\mathrm{HEF}_{33}$ can further be worked on to get their structures and other necessary properties needed for formulation into newer antibiotics.

In conclusion, the hexane extract and fractions of Alchornea cordifolia leaf possess broad spectrum of antibacterial activity against the test bacteria species. Five out of the thirty-three fractions displayed potential antibacterial activity that can be explored as remedy for human bacterial infections. The results obtained from this work gives high hope for the development of new antibacterial agents.

\section{References}

[1] Abdullahi M, Mohammad G, Abdukadir NU. (2003). Medicinal and Economic Plants of Nupe Land, $1^{\text {st }}$ edition, Jube-Evans Books and Publications, Bida, Nigeria. pp. 106107.

[2] Adeshina GO, Onaolapo JA, Ehinmidu JO, Odama LE. (2010). Phytochemical and Antimicrobial Studies of the Ethyl Acetate Extract of Alchornea cordifolia Leaf found in Abuja, Nigeria. J. Med. Plants Res. 4(8): 649-658.

[3] Adeshina GO. (2005). Phytochemical and Antimicrobial Studies of the Leaf of Alchornea cordifolia (Schum. \& Thonn.) Muell. Arg. (Euphorbiaceae). A Ph.D thesis of the Ahmadu Bello University, Zaria, Nigeria.

[4] Amos-Tautua, B.M.W., Angaye, S.S., Jonathan, G. (2011). Phytochemical Screening and Antimicrobial Activity of the Methanol and Chloroform Extracts of Alchornea cordifolia. J. Emerging Trends Engineer. App. Sci. 2(3): 445-447.

[5] Banso A, Adeyemi SO. (2007). Evaluation of Antibacterial Properties of Tannins Isolated from Dichrostarchys cinerea. Afr. J. Biotechnol. 6(15): 1785-1787.

[6] Brooks GF, Butel JS, Morse SA. (2004). Jawetz, Melnick and Adelberg's Medical Microbiology. 24th ed. Lange Med. Brooks/McGraw-Hill. pp. 203 - 642.

[7] Costantino L, Raimondi L, Pirisimo R, Brunetti T, Pessoto P, Giannessi F, Lins AP, Barlocco D, Antolini L, El-Abady, SA. Isolation and Pharmacological Activities of the Tecoma stans Alkaloids. 11 Farmaco 58(9): 781-785.

[8] Dalziel JM. (1956). The Useful Plants of West Tropical Africa, 3 $3^{\text {rd }}$ edition, Crown Agents for Oversea Government and Administration, Millbank, London. pp. 455.

[9] Doss A, Mohammed Mubarak H, DHanabalan R. (2009). Antibacterial Activity of Tannins from the leaves of Solanum trilobatum Linn. Indian J. Sci. Technol. 2(2): 41-43.

[10] El-Mahmood AM. (2009). Antibacterial activity of crude extracts of Euphorbia hirta against some bacteria associated with enteric infections, J. Med. Plants Res. 3(7):498-505.

[11] Erdemoglu N, Ozkan S, Tosun F. (2007). Alkaloid Profile and Antimicrobial Activity of Lupirius angustifolius L. Alkaloid Extract. Phytochem. Reviews. 6(1): 197-201.

[12] Gbile ZO, Adeshina SK. (1986). Nigerian Flora and its Pharmaceutical Potentials, Mediconsult, 31:7-16.

[13] Ghana Herbal Pharmacopoiea. (1992). Alchornea, $1^{\text {st }}$ edition, The advent Press, Accra, pp. 7-8.

[14] Kambezi L. Afolayan, AJ. (2008). Extracts from Aloe ferox and Withania somnifera inhibit Candida. Albicans and Neisseria gonorrhea. Afr. J. Biotechnol. 7 (1):012-015. 
[15] Kambu K, Tona L, Kaba S, Cimanga K, Mukala N. (1990). Antispasmodic Activity of Extracts Proceeding of Plant, Antidiarrhoeic Traditional Preparations used in Kinshasa, Zaire, Ann Pharm FR. 48(4):200-208.

[16] Le Grand A, Wondergem PA. (1987). Antiinfective Phytotherapy of the Savannah Forests of Senegal (East Africa), An Inventory, J. Ethnopharmacol. 21(2):109-125.

[17] Le Grand A. (1989). Anti-infectious Phytotherapy of the Tree-Savannah, Senegal (West Africa) III; A Review of the Phytochemical Substances and Anti-microbial Activity of 43 Species, J. Ethnopharmacol. 25(3):315-338.

[18] Macfoy CA, Sama AM.(1990). Medicinal Plants in Pujehun District of Sierra Leone, J. Ethnopharmacol. 30(3):610-632.

[19] Marcek K. (1972). Pharmaceutical Application of Thin Layer and Paper Chromatography, 2nd edition, Elsevier Publishing Company, London, pp. 357-369.

[20] Muanza DN, Kim BW, Euter KL, Williams L. (1994). Antibacterial and Antifungal Activities of Nine Medicinal Plants from Zaire, Int. J. Pharmacog. 32(4):337-345.

[21] National Committee for Clinical Laboratory Standard (2002). Performance Standard for Antimicrobial Disc Susceptibility Testing. Twelfth International Supplement. Approved standard M100-S12. National Committee for Clinical Laboratory Standards, Wayne, Pa.

[22] Nikitina VS, Kuz`mina LYu, Melentíev AL, Shendel GV. (2007). Antibacterial activity of Polyphenolic Compounds Isolated from Plants of Geraniaceae and Rosaceae families. Appl. Biochem. Microbiol. 43(6): 629 - 634.

[23] Ogungbamila FO, Samuelsson G. (1990). Smooth Muscle Relaxing Flavonoids from Alchornea cordifolia. Acta. Pharm. Nordica. 2(6): 421- 422.

[24] Rafael L, Teresinha N, Moritz JC, Maria IG, Eduardo MD, Tania SF. (2009). Evaluation of Antimicrobial and Antiplatelet Aggregation Effect of Solidago chilensis eyen. Int. J. Green Pharm. 3: 35 - 39.

[25] Rojas JJ, Ochoa VJ, Ocampo SA, Munöz J. (2006). Screening for Antimicrobial Activity of Ten Medicinal Plants Used in Colombian Folkloric Medicine: A Possible Alternative in the Treatment of Non-nosocomial Infections. BMC Complementary Altern. Med. 6: 2.

[26] Sweetman, S. (2005). Sweetman S (Ed), Martindale: The Complete Drug Reference. London: Pharmaceutical Press. Electronic version.

[27] Trease EG, Evans WC. (1993).Textbook of Pharmacognosy. 3 rd ed. London: Bailliere Tindal; 1993. p. 81-90, 268-98.

[28] Udobi CE, Onaolapo JA, Agunu A. (2008). Antibacterial Activities and Bioactive Components of the Aqueous Fraction of the Stem Bark of Parkia bigblobosa (JACQ) (Mimosaceae). Nig. J. Pharm. Sci. 7(1): 49-55.

[29] Uwumarongie, OH., Obasuyi,O and Uwumarongie, EG (2007). Phytochemical Analysis and Antimicrobial Screening of the Root of Jatropha tanjorensis. Chem. Tech. J. 3: 445-448.

[30] Wiley JM, Sherwood LM, Woolverton CJ. (2008). Presscott, Harley and Klein's Microbiology. 7th ed. McGraw-Hill Companies, Inc; pp. 859-882. 


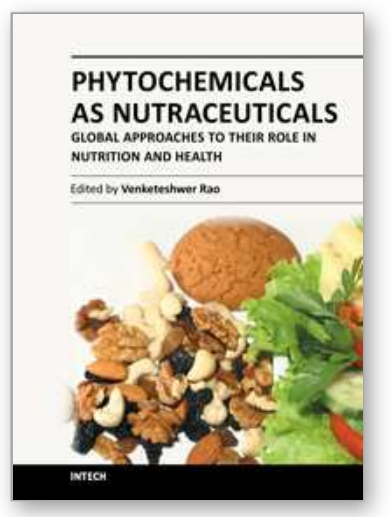

\author{
Phytochemicals as Nutraceuticals - Global Approaches to Their \\ Role in Nutrition and Health \\ Edited by Dr Venketeshwer Rao
}

ISBN 978-953-51-0203-8

Hard cover, 278 pages

Publisher InTech

Published online 23, March, 2012

Published in print edition March, 2012

Phytochemicals are biologically active compounds present in plants used for food and medicine. A great deal of interest has been generated recently in the isolation, characterization and biological activity of these phytochemicals. This book is in response to the need for more current and global scope of phytochemicals. It contains chapters written by internationally recognized authors. The topics covered in the book range from their occurrence, chemical and physical characteristics, analytical procedures, biological activity, safety and industrial applications. The book has been planned to meet the needs of the researchers, health professionals, government regulatory agencies and industries. This book will serve as a standard reference book in this important and fast growing area of phytochemicals, human nutrition and health.

\title{
How to reference
}

In order to correctly reference this scholarly work, feel free to copy and paste the following:

G.O. Adeshina, O.F. Kunle, J.A. Onaolapo, J.O. Ehinmidu and L.E. Odama (2012). Phytochemical and Antibacterial Studies of the Hexane Extract of Alchornea cordifolia Leaf, Phytochemicals as Nutraceuticals Global Approaches to Their Role in Nutrition and Health, Dr Venketeshwer Rao (Ed.), ISBN: 978-953-51-02038, InTech, Available from: http://www.intechopen.com/books/phytochemicals-as-nutraceuticals-globalapproaches-to-their-role-in-nutrition-and-health/phytochemical-and-antibacterial-studies-of-hexane-extract-ofalchornea-cordifolia-leaf

\section{INTECH}

open science | open minds

\section{InTech Europe}

University Campus STeP Ri

Slavka Krautzeka 83/A

51000 Rijeka, Croatia

Phone: +385 (51) 770447

Fax: +385 (51) 686166

www.intechopen.com

\section{InTech China}

Unit 405, Office Block, Hotel Equatorial Shanghai

No.65, Yan An Road (West), Shanghai, 200040, China

中国上海市延安西路65号上海国际贵都大饭店办公楼 405 单元

Phone: +86-21-62489820

Fax: $+86-21-62489821$ 
(C) 2012 The Author(s). Licensee IntechOpen. This is an open access article distributed under the terms of the Creative Commons Attribution 3.0 License, which permits unrestricted use, distribution, and reproduction in any medium, provided the original work is properly cited. 